\title{
Neurokinin-1 Receptor-Expressing Neurons in the Amygdala Modulate Morphine Reward and Anxiety Behaviors in the Mouse
}

\author{
Christopher A. Gadd, ${ }^{1 \star}$ Patricia Murtra, ${ }^{1,2 \star}$ Carmen De Felipe, ${ }^{2}$ and Stephen P. Hunt ${ }^{1}$ \\ ${ }^{1}$ Department of Anatomy and Developmental Biology, University College London, London, WC1E 6BT, United Kingdom, and ${ }^{2}$ Instituto de Neurociencias, \\ Universitas Miguel Hernández, Alicante 03550, Spain
}

\begin{abstract}
Mice lacking the neurokinin-1 $\left(\mathrm{NK}_{1}\right)$ receptor, the preferred receptor for the neuropeptide substance $\mathrm{P}$ (SP), do not show many of the behaviors associated with morphine reward. To identify the areas of the brain that might contribute to this effect, we assessed the behavioral effects of ablation of neurons expressing the $\mathrm{NK}_{1}$ receptor in specific regions of the mouse brain using the neurotoxin substance P-saporin. In a preliminary investigation, bilateral ablation of these neurons from the amygdala, but not the nucleus accumbens and dorsomedial caudate putamen, brought about reductions in morphine reward behavior. Subsequently, the effect of ablation of these neurons in the amygdala on anxiety behavior was assessed using the elevated plus maze (EPM), before conditioned place preference (CPP), and locomotor responses to morphine were measured. Loss of $\mathrm{NK}_{1}$ receptor-expressing neurons in the amygdala caused an increase in anxiety-like behavior on the EPM. It also brought about a reduction in morphine CPP scores and the stimulant effect of acute morphine administration relative to saline controls, without affecting CPP to cocaine. $\mathrm{NK}_{1}$ receptor-expressing neurons in the mouse amygdala therefore modulate morphine reward behaviors. These observations mirror those observed in $\mathrm{NK}_{1}$ receptor knock-out $\left(\mathrm{NK}_{1}{ }^{-l-}\right)$ mice and suggest that the amygdala is an important area for the effects of SP and the $\mathrm{NK}_{1}$ receptor in the motivational properties of opiates, as well as the control of behaviors related to anxiety.
\end{abstract}

Key words: neurokinin-1 receptor; substance P; substance P-saporin; morphine; reward; conditioned place preference; anxiety; elevated plus maze; amygdala; nucleus accumbens

\section{Introduction}

Substance $\mathrm{P}$ (SP) and its preferred receptor, the neurokinin-1 $\left(\mathrm{NK}_{1}\right)$ receptor, are expressed in many areas of the brain involved in affective behaviors, including the hypothalamus, amygdala, and nucleus accumbens (NAcc) (Nakaya et al., 1994). Recent work has provided evidence that $\mathrm{NK}_{1}{ }^{-1-}$ mice are insensitive to opiates in models of drug abuse (Murtra et al., 2000; Ripley et al., 2002). First, in the conditioned place preference (CPP) paradigm, $\mathrm{NK}_{1}{ }^{-1-}$ mice fail to develop a preference for an environment paired with morphine treatment, suggesting an impairment of the rewarding effects of the drug. They also self-administer morphine at lower levels than wild-type controls, and they fail to show an acute locomotor stimulant effect of the drug or to sensitize to its locomotor effects. These effects are specific to opiates, because behaviors associated with cocaine are unaffected by the genetic manipulation. In addition to a loss of the rewarding response to morphine, the mice show an impairment of both the physical and the motivational aspects of opiate withdrawal. De-

\footnotetext{
Received May 1, 2003; revised June 17, 2003; accepted June 21, 2003.

This work was supported by The Wellcome Trust. C.A.G. is in The Wellcome Trust 4 year PhD program in Neuroscience at University College London. We thank Dr. H. Bester and Dr. N. Jeffery for assistance with surgery.

${ }^{*}$ C.A.G. and P.M. contributed equally to this work.

Correspondence should be addressed to Prof. S. P. Hunt, Department of Anatomy and Developmental Biology, Medawar Building, University College London, Gower Street, London, WC1E 6BT, UK. E-mail: hunt@ucl.ac.uk. Copyright $\odot 2003$ Society for Neuroscience $\quad 0270-6474 / 03 / 238271-10 \$ 15.00 / 0$
}

spite the loss of the rewarding and addictive properties of morphine, De Felipe et al. (1998) found that the analgesic properties of morphine were not impaired in $\mathrm{NK}_{1}{ }^{-1-}$ mice in the hotplate test, indicating that the $\mathrm{NK}_{1}$ receptor is not critically involved in opiate analgesia. These results therefore suggest that the $\mathrm{NK}_{1}$ receptor plays a critical and specific role in the motivational, but not analgesic, properties of opiates, whereas it is not critical for the motivational properties of cocaine.

To gain more information about the location of the effects of this receptor in these behaviors, we assessed the effects of ablation of neurons expressing the $\mathrm{NK}_{1}$ receptor on the motivational properties of morphine. Ablation was achieved using the neurotoxin SP-saporin (SAP), a conjugate of SP with the ribosomeinactivating protein SAP from the seeds of the plant Saponaria officinalis. Because SAP cannot cross the plasma membrane alone, conjugation of SAP to SP allows the toxin to enter cells expressing the $\mathrm{NK}_{1}$ receptor and to reach the ribosomes, leading to cell death (Wiley and Lappi, 1997). SP-SAP and related compounds have already been used to demonstrate a role for $\mathrm{NK}_{1}$ receptor-expressing neurons in hyperalgesia and chronic pain (Mantyh et al., 1997; Nichols et al., 1999), the control of ejaculation (Truitt and Coolen, 2002), and the control of respiratory rhythm and blood pressure (Wang et al., 2002).

The NAcc and amygdala were selected for investigation in a preliminary study because they express $\mathrm{NK}_{1}$ receptors and have 
been implicated in the mediation of reward behaviors (Nakaya et al., 1994; Robbins and Everitt, 1996; Di Chiara et al., 1999). Following promising findings, the effects of cell ablation in the amygdala were assessed more thoroughly in a subsequent set of experiments. Given the known role of the $\mathrm{NK}_{1}$ receptor in the modulation of anxiety (Kramer et al., 1998; Rupniak et al., 2000; Santarelli et al., 2001), these mice were also tested for anxiety behavior using the elevated plus maze (EPM).

\section{Materials and Methods}

Animals. Male mice were used in all experiments. They were housed in groups of two to five at $21^{\circ} \mathrm{C}$ and $50 \%$ relative humidity, with water and food ad libitum, except during surgery and behavioral testing. Lights were programmed on a $12 \mathrm{hr}$ light/dark cycle (lights on at 8:00 A.M.). Experiments were begun when mice were 6-8 weeks old. Wild-type C57BL/6 mice were purchased from Harlan Olac (Bicester, UK). Wildtype C57BL/6 $\times$ SV/129 mice were bred in-house from male C57BL/6 and female $129 \mathrm{~S} 2 / \mathrm{Sv}$ mice (Harlan Olac). Heterozygous $\mathrm{NK}_{1}{ }^{+/-}$and homozygous $\mathrm{NK}_{1}{ }^{-1-}$ mice were derived from those used by De Felipe et al. (1998), outcrossed onto an MF1 background (Harlan Olac). The genotype of these mice was verified using PCR of tail-tip DNA. All procedures were performed in accordance with the United Kingdom Animals (Scientific Procedures) Act of 1986.

Stereotaxic surgery. Substances were delivered bilaterally to discrete areas of the mouse brain stereotaxically. Injection sites were determined using a mouse brain atlas (Franklin and Paxinos, 1997) and verified in preliminary studies. Distances of injection sites from bregma were as follows (in $\mathrm{mm}$ ): NAcc, anteroposterior (AP), 1.2; mediolateral (ML), \pm 1.0 ; dorsoventral (DV), 4.2; amygdala, AP, -1.5 ; ML, \pm 2.8 ; DV , 4.8.

Mice were anesthetized with inhaled halothane in oxygen (flow rate, $0.6 \mathrm{l} / \mathrm{min}$ ), at a concentration at which there was no motor response to a foot pinch but at which breathing rate and depth were normal. They were placed on a heated pad in a stereotaxic frame (model 900 Small Animal Stereotaxic Instrument; David Kopf Instruments, Tujunga, CA) fitted with a Mouse Adaptor (David Kopf Instruments). Rat ear bars (David Kopf Instruments) were positioned against the skull of the mouse to hold the head still. The hair over the scalp was trimmed, and the skin was swabbed with $10 \%$ povidone-iodine solution (Betadine Antiseptic Solution; Seton Healthcare Group, Oldham, UK). A midline incision was made, exposing the skull. The positions of the Mouse Adaptor and ear bars were adjusted until the skull was level, before holes (diameter, 1 $\mathrm{mm}$ ) were drilled through the skull above the injection sites. A $5 \mu \mathrm{l}$ Hamilton Microliter Syringe (700 Series; Hamilton Bonaduz, Bonaduz, Switzerland) fitted with a 22 gauge needle (RN Series; Hamilton Bonaduz) was attached to the stereotaxic frame via a Universal Holder (David Kopf Instruments). The needle was moved to the injection site and inserted slowly into the brain. It was left in position for $5 \mathrm{~min}$ before $1.0 \mu \mathrm{l}$ of the injection solution (see below) was injected over $10 \mathrm{~min}$ $(\sim 0.1 \mu$ l every minute). After injection, the needle was left in place for an additional $5 \mathrm{~min}$ to allow diffusion of the solution, before it was slowly removed from the brain. After both injections had been made, the incision was sutured and dusted with Cicatrin powder (The Wellcome Foundation, Greenford, UK). The mouse was then removed from the stereotaxic apparatus, given a subcutaneous injection of $1 \mathrm{ml}$ of sterile saline, and left in a warm place to recover.

Elevated plus maze. Anxiety levels were assessed using the EPM, which exploits the conflict between the animal's innate tendency to explore novel areas with their aversion for heights and open spaces (Montgomery, 1955; Handley and Mithani, 1984). It consisted of four black Plexiglas runways $(300 \times 49 \mathrm{~mm})$ arranged in a cross shape and connected by a square central zone $(49 \times 49 \mathrm{~mm})$. The maze was raised $300 \mathrm{~mm}$ above the floor. Two opposite arms of the apparatus ("closed arms") had 150 $\mathrm{mm}$ high clear Plexiglas walls surrounding the runways, whereas the remaining two arms ("open arms") were not enclosed. The maze was used under low-light conditions (4 lux).

Mice were placed individually on the central portion of the apparatus, facing an open arm. They were left to explore the apparatus for $5 \mathrm{~min}$ and were recorded using a video camera. At the end of the session, the mice were returned to the home cage, and the apparatus was thoroughly cleaned with water.

After recording, the time spent in and the number of entries made into the arms of the maze were scored. An "entry" was defined as movement of all four paws into an arm. Time spent in the central zone of the maze was discounted, with time spent in the open arms of the maze expressed as a percentage of the total time spent in any arm. The number of entries into the open arms was calculated as a percentage of the total number of entries into any of the arms.

Conditioned place preference. CPP was used as a measure of the rewarding properties of morphine or cocaine (Bechara and van der Kooy, 1992; Bardo and Bevins, 2000). The apparatus consisted of two white Plexiglas compartments $(146 \times 138 \times 141 \mathrm{~mm})$ separated by a central neutral zone $(50 \times 138 \times 141 \mathrm{~mm})$. One compartment had black horizontal stripes painted on the walls and floor, and the other had black spots painted on the walls and floor with a metal grid on the floor.

During the preconditioning phase, each mouse was placed in the apparatus with free access to all compartments for $18 \mathrm{~min}$. The amount of time spent in each compartment was measured using EthoVision 2.3 (Noldus Information Technology, Wageningen, The Netherlands). Time spent in the central neutral zone was disregarded. Mice spending $>75 \%$ of the remaining time in one of the two compartments were excluded from the remainder of the experiment. During the subsequent conditioning phase, mice were given intraperitoneal injections of the drug under test (see below) and vehicle on alternate days for $6 \mathrm{~d}$. Immediately after injection, they were confined to one of the two compartments for 20 min, with drug and vehicle being assigned to the two opposite compartments in a counterbalanced, unbiased manner. In the final test session, mice were again allowed to explore both compartments for $18 \mathrm{~min}$, with the amount of time spent in each being recorded. The apparatus was cleaned thoroughly with water after use.

The rewarding nature of the drug under test was assessed by calculating the increase in the amount of time spent in the drug-associated compartment after conditioning relative to that in the preconditioning phase ("CPP score").

Assessment of locomotor activity. Mice were placed individually in a square black arena $(410 \times 410 \mathrm{~mm}$; Columbia Instruments $)$ with 14 parallel infrared beams ( $27 \mathrm{~mm}$ apart and $28 \mathrm{~mm}$ above the floor) projecting across to detector cells on the opposite wall. The number of beam crosses made in $10 \mathrm{~min}$ was used as a measure of locomotor activity. The apparatus was cleaned thoroughly with water after use.

Immunohistochemistry. At the end of behavioral testing, mice were terminally anesthetized by an intraperitoneal injection of $0.2 \mathrm{ml}$ of pentobarbitone sodium (Euthatal; 200 mg/ml; Rhône Mérieux, Harlow, UK) and perfused intracardially with $50 \mathrm{ml}$ of heparinized PBS, followed by $100 \mathrm{ml}$ of ice-cold 4\% paraformaldehyde (PFA) (BDH Laboratory Supplies, Poole, UK) in $0.15 \mathrm{~m}$ phosphate buffer (PB). Brains were removed and postfixed for $4-5 \mathrm{hr}$ in $4 \% \mathrm{PFA}$ at $4^{\circ} \mathrm{C}$. They were then cryoprotected in $30 \%$ sucrose in $0.1 \mathrm{M} \mathrm{PB}$ with $0.02 \% \mathrm{NaN}_{3}$ at $4^{\circ} \mathrm{C}$ for at least $12 \mathrm{hr}$ before being sectioned on a freezing microtome at $40 \mu \mathrm{m}$. Sections were collected in $5 \%$ sucrose in $0.1 \mathrm{M} \mathrm{PB}$ containing $0.02 \% \mathrm{NaN}_{3}$ and stored at $4^{\circ} \mathrm{C}$. Immunohistochemistry (IHC) was performed at room temperature on free-floating sections in $0.1 \mathrm{M} \mathrm{PB}$ containing $0.03 \%$ Triton X-100 (BDH Laboratory Supplies) and $0.03 \%$ normal serum of the animal in which the secondary antibody was raised (Vector Laboratories, Burlingame, CA). Sections were washed in $0.1 \mathrm{M} \mathrm{PB}$ three times for $10 \mathrm{~min}$ between steps. Primary antibodies used were raised against the $\mathrm{NK}_{1}$ receptor (1:10,000; Eurogentec, Seraing, Belgium), glial fibrillary acidic protein (GFAP) (1:1000; Dako, Glostrup, Denmark), choline acetyltransferase (ChAT) (1:1000; Chemicon, Temecula, CA), or neuronal nuclei (NeuN) (1:1000; Chemicon). Sections were incubated in the primary antibody for $18 \mathrm{hr}$. For the $\mathrm{NK}_{1}$ receptor, primary antibodies were visualized using biotinylated anti-rabbit IgG [heavy and light $(\mathrm{H}+\mathrm{L})$ ] made in goat (1:200 for $2 \mathrm{hr}$; Vector Laboratories), followed by fluorescein avidin D (1:200 for $1 \mathrm{hr}$; Vector Laboratories). For GFAP, detection was achieved using fluorescein anti-rabbit $\operatorname{IgG}(\mathrm{H}+\mathrm{L})$ made in goat $(1: 200$ for $3 \mathrm{hr}$; Vector Laboratories). For ChAT, detection was achieved using fluorescein anti-goat $(\mathrm{H}+\mathrm{L})$ made in rabbit $(1: 200$ for $3 \mathrm{hr}$; Vector Laboratories). For NeuN, detection was achieved using Texas Red-X goat 
anti-mouse IgG ( H + L) (1:200 for 3 hr; Molecular Probes, Leiden, The Netherlands). Sections were mounted onto Superfrost Plus microscope slides (BDH Laboratory Supplies) and coverslipped with Prolong Antifade kit (Molecular Probes). Sections were viewed using a Nikon (Kingston upon Thames, UK) Eclipse E800 microscope and photographed using a Hamamatsu Photonics (Welwyn Garden City, UK) Chilled CCD camera (model C5985) connected to a Macintosh PowerPC G3 computer (Apple Computers, Cupertino, CA) running Vision Explorer VA 1.11 (Graftek Imaging, Austin, TX). Histological findings were compared and agreed by two observers who were unaware of the behavioral results.

Preliminary investigation: comparison of effects of ablation in nucleus accumbens and amygdala. Forty-five C57BL/6 mice were used in this experiment. They were divided into three groups: two received bilateral injections of SP-SAP (1.0 $\mu \mathrm{l}, 1.00 \mu \mathrm{M}$; Advanced Targeting Systems, San Diego, CA) into the NAcc $(n=16)$ or the amygdala $(n=17)$. The third group of 12 mice was used as naive controls. Three mice died during the experimental procedure.

Five weeks after surgery, all mice were tested for CPP to morphine sulfate $(3.0 \mathrm{mg} / \mathrm{kg}$ and $6.67 \mathrm{ml} / \mathrm{kg}$; Sigma, Poole, UK). Three mice showed preference for one of the two compartments during preconditioning (one from the NAcc group and two from the amygdala group) and were omitted from analysis. After the behavioral experiment, mice were perfused, and their brains removed, postfixed, cryoprotected, and sectioned. IHC for the $\mathrm{NK}_{1}$ receptor was performed on every fourth section through the brain. The remaining sections were processed for IHC for GFAP, ChAT, or NeuN. The loss of $\mathrm{NK}_{1}$ receptor immunoreactivity was assessed in each mouse with reference to that of naive animals. Mice with no visible bilateral loss of $\mathrm{NK}_{1}$ receptor-expressing neurons in the brain region of interest were excluded from analysis, as were mice with visible physical damage to the brain or bilateral loss of $\mathrm{NK}_{1}$ receptor immunoreactivity in any other brain region. In mice injected with SPSAP in the NAcc, ChAT immunoreactivity was used as a secondary marker of $\mathrm{NK}_{1}$ receptor-expressing cells. Sections stained with $\mathrm{NeuN}$ and GFAP were also compared with control mice's sections. Major decreases in neuronal nuclear staining or increases in GFAP immunoreactivity were considered as signs of nonspecific damage caused by the injection procedure.

Analysis of effects of ablation in amygdala on anxiety and morphine reward behaviors. Because the C57BL/6 mice used in the preliminary experiment were found to exhibit highly variable CPP scores to morphine, hybrid C57BL/ $6 \times 129 \mathrm{~S} 2 / \mathrm{Sv}$ mice $(n=182)$ were used in this subsequent experiment, because this strain is similar to that used by Murtra et al. (2000). They received bilateral injections of SP-SAP (1.0 $\mu \mathrm{l}$, $1.00 \mu \mathrm{M} ; n=78)$, SP $(1.0 \mu \mathrm{l}, 1.00 \mu \mathrm{M} ; n=28$; Sigma $)$, or SAP $(1.0 \mu \mathrm{l}, 1.00$ $\mu \mathrm{M} ; n=40$; Advanced Targeting Systems) in the amygdala. The remaining 36 mice were used as naive controls. Five mice died during the experimental procedure. Each of the four groups of mice was subdivided into two additional groups (SP-SAP: group I, $n=38$; group II, $n=37$; SP: group I, $n=15$; group II, $n=12$; SAP: group I, $n=21$; group II, $n=18$; naive, group I, $n=18$; group II, $n=18$ ).

Five weeks after surgery, mice in both groups were assessed for anxiety behavior on the EPM. One day later, mice in group I were given an injection of sterile saline $(10.0 \mathrm{ml} / \mathrm{kg}) 30 \mathrm{~min}$ before locomotor activity was monitored. Beginning 3-5 d after locomotor assessment, they were tested for CPP to morphine sulfate $(3.0 \mathrm{mg} / \mathrm{kg}$ and $10.0 \mathrm{ml} / \mathrm{kg})$. Thirtyeight animals demonstrated a preference for one of the compartments during preconditioning and were excluded from the remainder of the behavioral experiment.

Beginning $1 \mathrm{~d}$ after testing on the EPM, group II mice underwent CPP with saline $(10.0 \mathrm{ml} / \mathrm{kg})$. Mice that demonstrated a preference for one of the two compartments during preconditioning $(n=30)$ were not removed from the experiment but were assigned to receive the first injection of saline in one of the two compartments at random. These mice underwent the entire CPP procedure, but their CPP scores were omitted from statistical analysis. Three to $5 \mathrm{~d}$ after the test session, the locomotor effects of morphine $(10.0 \mathrm{mg} / \mathrm{kg}$ and $10.0 \mathrm{ml} / \mathrm{kg})$ were assessed $30 \mathrm{~min}$ after injection. The order of the two tests was swapped between the two groups to ensure that morphine injections occurred during the final behavioral test.
After the behavioral experiments, mice were perfused, and their brains removed, postfixed, cryoprotected, and sectioned. IHC was performed for the $\mathrm{NK}_{1}$ receptor, NeuN, and GFAP. The position and extent of loss of $\mathrm{NK}_{1}$ receptor-expressing neurons in the amygdala was assessed in the brains of mice from the SP-SAP group. Animals were omitted from analysis unless they had a clear reduction of $\mathrm{NK}_{1}$ receptor immunoreactivity throughout the amygdala on both sides of the brain. Animals with visible necrosis or bilateral loss of $\mathrm{NK}_{1}$ receptor-expressing neurons in any other brain region were also omitted. For the remaining three groups of mice (SP, SAP, and naive), the integrity of $\mathrm{NK}_{1}$ receptor immunoreactivity was checked throughout the brain. In all groups, nonspecific loss of neurons was assessed in sections processed for NeuN IHC, whereas gliosis was sought in sections processed for GFAP.

Analysis of effects of SP-SAP in the amygdala on cocaine reward. Hybrid $\mathrm{C} 57 \mathrm{BL} / 6 \times 129 \mathrm{~S} 2 / \mathrm{Sv}$ mice $(n=38)$ were used in this experiment. Twenty-two mice underwent bilateral injection of SP-SAP (1.0 $\mu \mathrm{l}, 1.00$ $\mu \mathrm{M})$ into the amygdala, and 16 were used as naive controls. Two mice died during surgery. Beginning 5 weeks after surgery, both groups of mice were tested for CPP to cocaine hydrochloride $(5.0 \mathrm{mg} / \mathrm{kg}$ and 10.0 $\mathrm{ml} / \mathrm{kg}$; Sigma). None of the mice displayed preference for one of the two compartments during preconditioning. After the behavioral experiments, the mice were perfused and processed for IHC as above.

Localization of ablated cells in the amygdala. Because the somata of $\mathrm{NK}_{1}$-expressing cells within the amygdala do not express the $\mathrm{NK}_{1}$ receptor, it is difficult to identify which cells are being eliminated by SP-SAP in this brain region using IHC. Because the reporter gene lac $Z$ is present in the cassette inserted into exon 1 of the $\mathrm{NK}_{1}$ receptor gene in $\mathrm{NK}_{1}{ }^{-1-}$ mice (De Felipe et al., 1998), the product of this gene, $\beta$-galactosidase $(\beta \mathrm{Gal})$, is expressed in the somata of the same cells that express the $\mathrm{NK}_{1}$ receptor in wild-type animals. These cells can be stained with 5-bromo4-chloro-3-indolyl- $\beta$-D-galactopyranoside (X-Gal), which, in the presence of $\beta \mathrm{Gal}$, forms a visible blue dimer. Furthermore, heterozygous $\mathrm{NK}_{1}{ }^{+/-}$mice express $\mathrm{NK}_{1}$ receptors and $\beta \mathrm{Gal}$ in the same cells. The loss of $\beta \mathrm{Gal}$-positive somata in these mice was therefore used as a marker of the cell population ablated by SP-SAP in the amygdala.

Two $\mathrm{NK}_{1}{ }^{-/-}$and three $\mathrm{NK}_{1}{ }^{+/-}$mice were used. The $\mathrm{NK}_{1}{ }^{+/-}$mice were injected unilaterally in the left amygdala with SP-SAP $(1.0 \mu \mathrm{l}, 1.00$ $\mu \mathrm{M})$. Five weeks after injection of the $\mathrm{NK}_{1}{ }^{+/-}$mice, all five mice were perfused, and their brains were removed, postfixed, cryoprotected, and sectioned. Every third section through the brain was stained for $\beta \mathrm{Gal}$ activity. Sections were washed twice for $10 \mathrm{~min}$ in $0.1 \mathrm{M} \mathrm{PB}$. They were then incubated in X-Gal staining solution (PBS [Dulbecco "A" solution; Oxoid, Basingstoke, UK], containing $5 \mathrm{~mm} \mathrm{~K}_{3} \mathrm{Fe}(\mathrm{CN})_{6}$ [Sigma], $5 \mathrm{~mm}$ $\mathrm{K}_{4} \mathrm{Fe}(\mathrm{CN})_{6}$ [Sigma], $2 \mathrm{~mm} \mathrm{MgCl}{ }_{2}$ [Sigma], $0.01 \%$ sodium deoxycholate [Sigma], 0.02\% Triton X-100 [BDH Laboratory Supplies], and 2\% X-Gal [Calbiochem, San Diego, CA; $50 \mathrm{mg} / \mathrm{ml}$ in dimethylformamide (BDH Laboratory Supplies)]) overnight at $37^{\circ} \mathrm{C}$ before two more washes in 0.1 м PB. Sections were mounted onto gelatin-coated slides and left to air dry. The sections were counterstained by immersion in $0.5 \%$ Neutral Red (Gurr Certistain; BDH Laboratory Supplies) in 1\% glacial acetic acid (BDH Laboratory Supplies) for 2-3 min. Sections were dehydrated through ethanol solutions of increasing strength and cleared in Histoclear (National Diagnostics, Hull, UK). Slides were coverslipped in DPX mounting medium (BDH Laboratory Supplies) and left to dry before being observed under bright-field microscopy. The distribution of $\beta \mathrm{Gal}$ positive cells was observed in the amygdalae of the mice, and the effect of SP-SAP in heterozygous mice was determined by comparing injected and uninjected sides.

Statistical analysis. Data are presented as mean \pm SEM. In the preliminary experiment, $\mathrm{CPP}$ scores from naive and SP-SAP-injected mice were compared using one-way ANOVAs for each injection site. In the subsequent experiment analyzing the effects of ablation of $\mathrm{NK}_{1}$ receptorexpressing neurons in the amygdala, EPM results were compared between treatment groups with one-way ANOVAs, followed by post hoc Tukey comparisons. Results from the CPP and locomotion experiments were analyzed using two-way ANOVAs with treatment and drug as between-subject factors, followed by post hoc Tukey comparisons. For all analyses, the homogeneity of the variance and normality of the error were verified. 


\section{Results}

Histological effects of SP-SAP injection in the nucleus accumbens and amygdala In naive mice, the $\mathrm{NK}_{1}$ receptor is visible on the somata and dendrites of large neurons within the shell and core subregions of the NAcc (Fig. 1A). Injection of SP$\mathrm{SAP}$ into the NAcc resulted in a clear loss of $\mathrm{NK}_{1}$ receptor immunoreactivity in a circular area of $\sim 1 \mathrm{~mm}$ diameter around the injection site (Fig. 1A). However, mice with ablation of these neurons also exhibited loss of $\mathrm{NK}_{1}$ receptor-expressing neurons at the dorsomedial edge of the caudate putamen $(\mathrm{CPu})$ adjacent to the lateral ventricle (Fig. 1B). This was presumably attributable to the toxin flowing back as the needle was removed from the brain. There was no visible reduction in the number of NeuN-labeled nuclei at the injection site in the NAcc and no increase in GFAP immunoreactivity, indicating that there was little nonspecific neuronal damage at the injection site (Fig. $1 C$ ). Because the proportion of cells expressing the $\mathrm{NK}_{1}$ receptor in this brain region is estimated to be low (1-2\%), the similar density of NeuN-labeled nuclei in SP-SAPinjected and naive mice is unsurprising. In addition, the ChAT-positive cells of the NAcc were missing at the site of the lesion (data not shown). Because ChAT is localized in most $\mathrm{NK}_{1}$-expressing interneurons of the striatum (Gerfen, 1991; Kaneko et al., 1993), this indicates that the observed loss of $\mathrm{NK}_{1}$ receptor immunoreactivity was probably caused by cell death rather than an inability for the $\mathrm{NK}_{1}$ receptor to be detected immunohistochemically.

In the amygdala, $\mathrm{NK}_{1}$ receptor immunoreactivity is visible in a subnucleus-specific pattern (Fig. $2 A$ ). In the central nucleus, a diffuse staining of the neuropil is visible, whereas in the basomedial and medial nuclei, a network of clearly stained dendrites can be seen. Within the basolateral and lateral nuclei, immunoreactivity is low intensity, although one or two immunoreactive neurons are often observed with clearly stained perikarya and dendrites. SP-SAP injected into the amygdala caused a loss of $\mathrm{NK}_{1}$ receptor immunoreactivity. A reduction in the intensity of staining was seen in the central nucleus, along with a loss of stained dendrites and occasional cell bodies in the basolateral, basomedial, lateral, and medial nuclei (Fig. 2A). There was no observable decrease in the number of NeuNlabeled nuclei at the site of injection and no increase in GFAP immunoreactivity (Fig. 2B). In mice injected with SP or SAP into the amygdala, $\mathrm{IHC}$ for the $\mathrm{NK}_{1}$ receptor, GFAP, and NeuN gave similar results to naive mice (Fig. $2 B$ ).

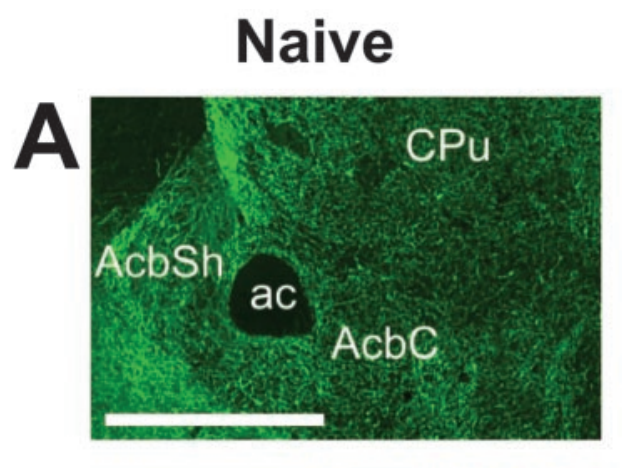

SP-SAP
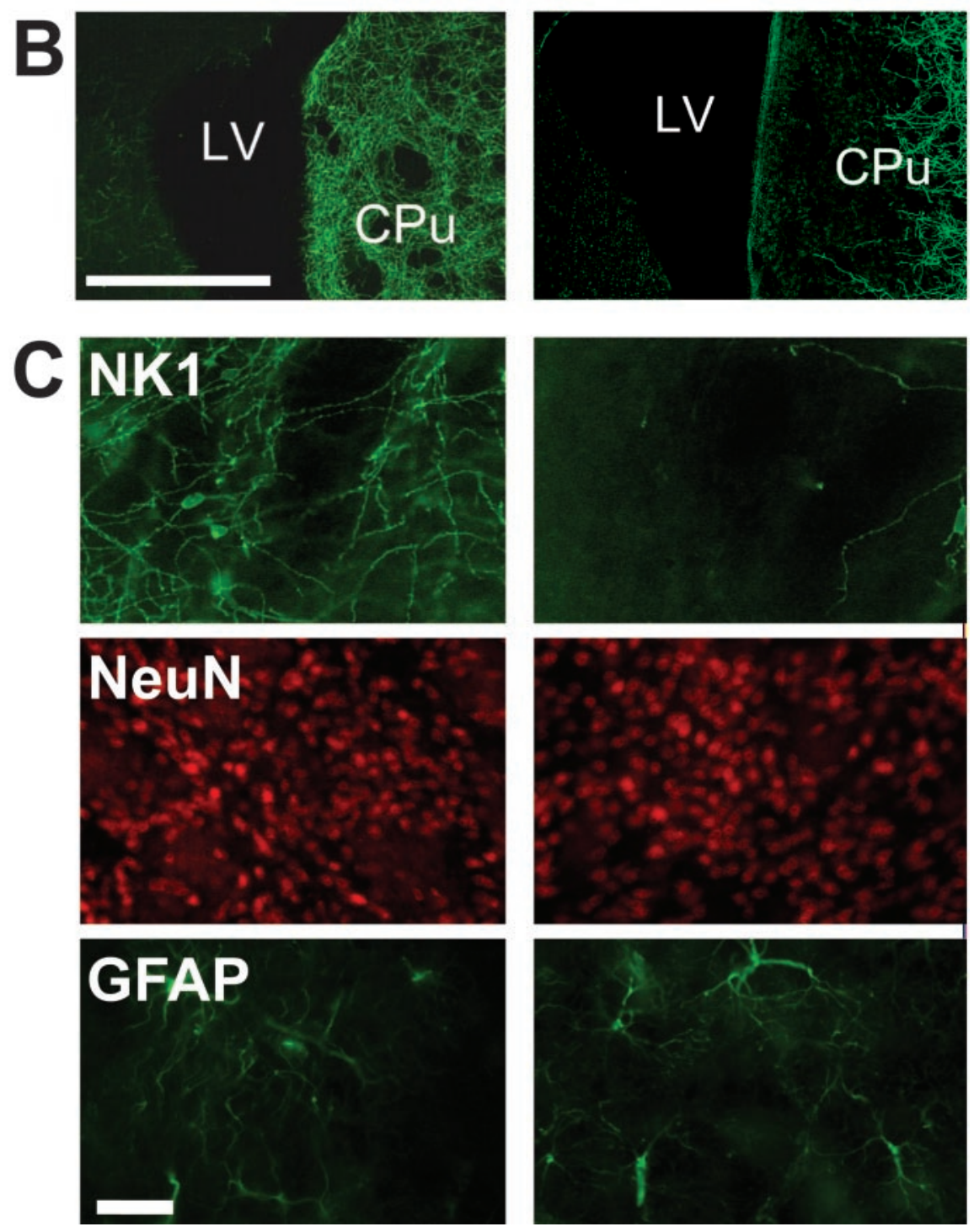

Figure 1. Effects of SP-SAP in the NAcc. A, Sections from the NAcc of a naive and SP-SAP-injected mouse stained immunohistochemically for the $\mathrm{NK}_{1}$ receptor. After 5 weeks, SP-SAP caused a clearance of $\mathrm{NK}_{1}$ receptor immunoreactivity around the injection site, in both the core (AcbC) and shell (AcbSh) regions. Scale bar, $1 \mathrm{~mm}$. B, Injection of SP-SAP into the NAcc caused the additional loss of neurons from the dorsomedial edge of the CPu, adjacent to the lateral ventricle (LV). Scale bar, $1 \mathrm{~mm}$. C, Sections from the NAcc core stained immunohistochemically for the $\mathrm{NK}_{1}$ receptor, NeuN, or GFAP. Loss of NK 1 receptor immunoreactivity at the injection site was not accompanied by nonspecific loss of neurons, as assessed by IHC for NeuN, or gliosis, as assessed by IHC for GFAP. Scale bar, $50 \mu \mathrm{m}$. ac, Anterior commissure.

\section{Localization of ablated cells in the amygdala}

In the amygdala of $\mathrm{NK}_{1}{ }^{-1-}$ mice, $\beta \mathrm{Gal}$-positive nuclei were observed diffusely through the basolateral, basomedial, central, and medial nuclei (Fig. 3A). Stained nuclei were more numerous in 


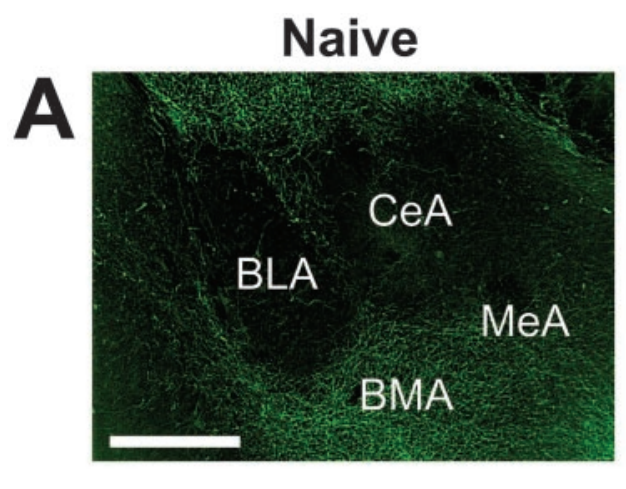

SP-SAP
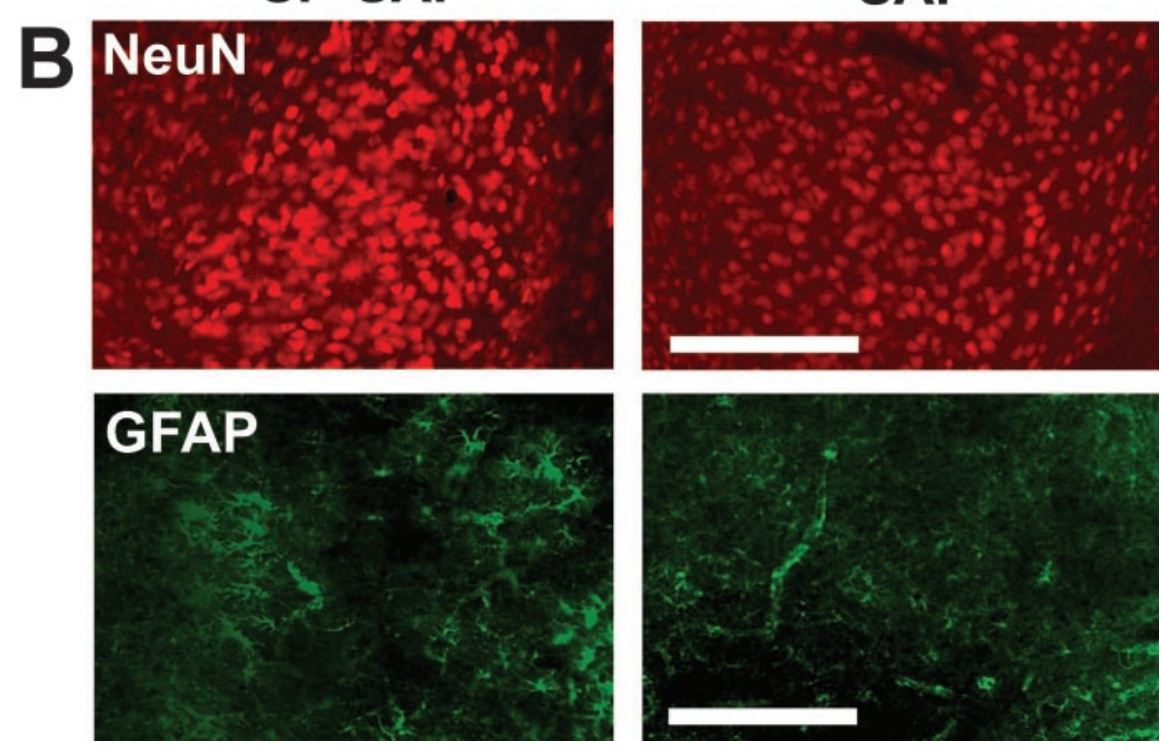

Figure 2. Effects of SP-SAP in the amygdala. A, Sections from the amygdala of a naive and SP-SAP-injected mouse stained immunohistochemically for the $\mathrm{NK}_{1}$ receptor. After 5 weeks, SP-SAP caused a reduction in $\mathrm{NK}_{1}$ receptor immunoreactivity around the injection site, particularly in the medial (MeA), basomedial (BMA), and central (CeA) nuclei. Scale bar, $1 \mathrm{~mm}$. B, Sections from the medial nucleus stained immunohistochemically for NeuN or GFAP. Loss of NK ${ }_{1}$ receptor immunoreactivity was not accompanied by loss of NeuN immunoreactivity or increases in GFAP immunoreactivity. Injection of SAP alone also failed to bring about loss of neurons or gliosis at the injection site. Sections from naive mice and SP-injected mice (data not shown) were similar to those injected with SAP. Scale bar, $250 \mu \mathrm{m}$. BLA, Basolateral nucleus of the amygdala.

the medial nucleus of the amygdala than other subnuclei. In the amygdala of $\mathrm{NK}_{1}{ }^{+/-}$mice, fewer $\beta \mathrm{Gal}$-positive nuclei were seen than in $\mathrm{NK}_{1}{ }^{-/-}$mice, but the relative distribution of the stained nuclei was similar to that seen in $\mathrm{NK}_{1}{ }^{-1-}$ mice. Injection of SP$\mathrm{SAP}$ into the amygdala resulted in a loss of $\beta \mathrm{Gal}$-positive nuclei in $\mathrm{NK}_{1}{ }^{+/-}$mice (Fig. $3 B$ ), suggesting that, although it is difficult to assess the precise location of the cells ablated by SP-SAP in the amygdala using IHC, their somata are distributed throughout the central, basolateral, and medial nuclei of the amygdala, but with a higher density in the medial nucleus.

\section{Preliminary findings: effects of SP-SAP injection into the} nucleus accumbens or amygdala on morphine reward In a preliminary study, the effects of ablation of $\mathrm{NK}_{1}$ receptorexpressing neurons in the NAcc and amygdala on morphine CPP behavior were compared. Because of the frequent loss of $\mathrm{NK}_{1}$ receptor-expressing neurons from the dorsomedial $\mathrm{CPu}$ after injection of SP-SAP into the NAcc, mice from this group were not excluded on the basis of additional ablation in this brain region. The NAcc group therefore contained mice that exhibited ablation of these cells in both the NAcc and the dorsomedial $\mathrm{CPu}$. The three mice that did not exhibit ablation in both of these regions were excluded, leaving 11 in this group. In the amygdala group, one mouse was excluded on the basis of histological examination, leaving 15.

Mice with ablation in the NAcc and dorsomedial $\mathrm{CPu}$ exhibited similar degrees of CPP to morphine to naive mice $\left(F_{(1,20)}=0.39 ; p=0.537\right)$ (Fig. 4). However, mice with ablation of $\mathrm{NK}_{1}$ receptorexpressing neurons in the amygdala exhibited lower CPP scores than naive mice $\left(F_{(1,24)}=4.88 ; p=0.037\right)$ (Fig. 4). Ablation of $\mathrm{NK}_{1}$ receptor-expressing neurons in the NAcc and dorsomedial CPu therefore had little effect on morphine reward behaviors. However, ablation of these neurons in the amygdala brought about a reduction in CPP scores, which suggests a reduction in the rewarding properties of morphine in these mice.

Analysis of effects of cell ablation in the amygdala on anxiety and morphine reward

Following the observation that ablation of $\mathrm{NK}_{1}$ receptor-expressing neurons in the amygdala, but not in the NAcc and dorsomedial $\mathrm{CPu}$, of mice brought about deficits in morphine reward behavior, a set of experiments was performed to extend these findings. The effects of $\mathrm{NK}_{1}$ receptor-expressing neuron ablation on morphine CPP were compared with vehicle controls to assess the effect of the morphine-independent aspects of the task. Control injections of the constituent molecules of SP-SAP were also attempted. SP was injected to control for the activation of $\mathrm{NK}_{1}$ receptors at the site of injection, and SAP injections were used to control for the nonspecific effects of toxin administration on cells other than those that express $\mathrm{NK}_{1}$ receptors. The injection of both substances also acted as controls for the stress and pain associated with handling, surgery, and the behavioral tasks undertaken. After surgery, the mice were tested for anxiety behavior, CPP to morphine or saline, as well as the locomotor response to an acute injection of saline or morphine, to compare the effects of ablation of $\mathrm{NK}_{1}$ receptor-expressing neurons in this brain region with the morphine-related behaviors that are disrupted in $\mathrm{NK}_{1}{ }^{-1-}$ mice.

After histological analysis, 48 mice from the SP-SAP group were omitted because of incomplete loss of $\mathrm{NK}_{1}$ receptorexpressing neurons (23 from group I and 25 from group II). No mice were omitted from the SP or SAP groups.

On the EPM, naive mice spent $37.7 \pm 4.0 \%$ of the time in the open arms of the maze, and $41.2 \pm 2.8 \%$ of the entries they made were into the open arms. Naive mice exhibited a clear CPP to morphine $\left(3.0 \mathrm{mg} / \mathrm{kg} ; F_{(1,24)}=6.35 ; p=0.019\right.$; data not shown) and locomotor stimulation $30 \mathrm{~min}$ after an acute injection of 

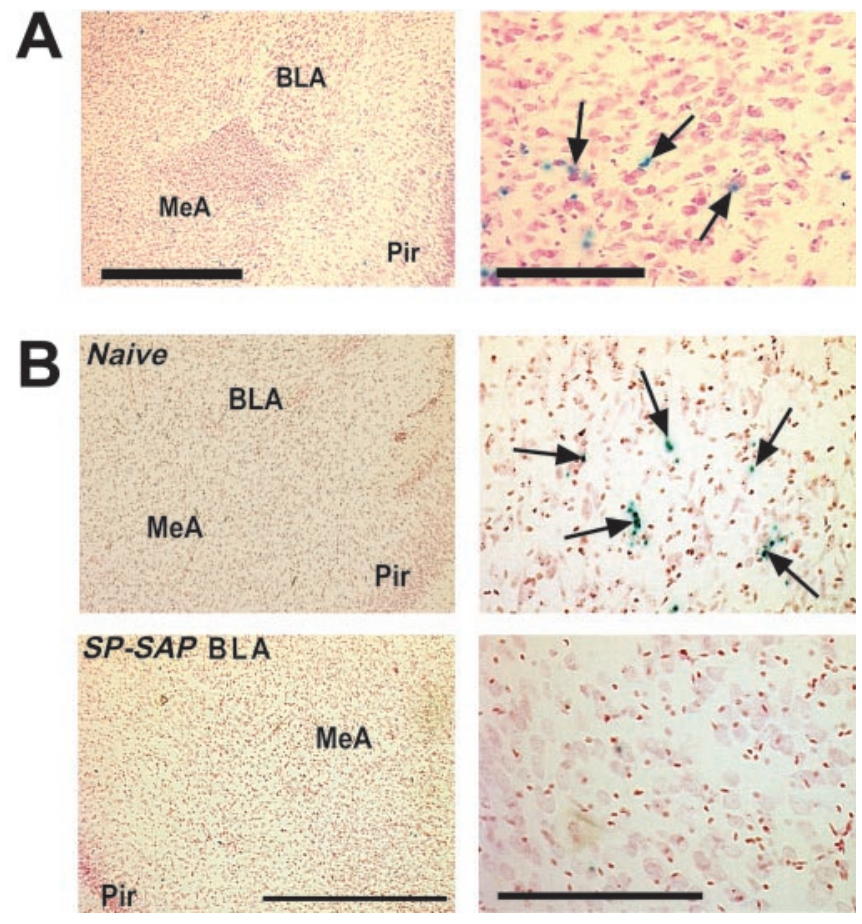

Figure 3. Localization of ablated cells in the amygdala. $A$, Sections of the amygdala of an $\mathrm{NK}_{1}{ }^{-1-}$ mouse stained with X-Gal and counterstained with neutral red. $\beta G$ al-positive cells are visible throughout the amygdala, notably in the medial nucleus. Right, Medial nucleus. Arrows indicate $\beta$ Gal-positive nuclei. Scale bars: left, $1 \mathrm{~mm}$; right, $250 \mu \mathrm{m}$. B, Sections from an $\mathrm{NK}_{1}{ }^{+/-}$mouse 5 weeks after unilateral injection of SP-SAP into the amygdala. On the uninjected (Naive) side of the brain, $\beta$ Gal-positive nuclei are present though the central, basolateral, and medial nuclei of the amygdala, but these are absent on the side of the brain injected with SP-SAP. Right, Medial nucleus. Scale bars: left, $1 \mathrm{~mm}$; right, $250 \mu \mathrm{m}$. BLA, Basolateral nucleus of the amygdala; MeA, medial nucleus of the amygdala; Pir, piriform cortex.

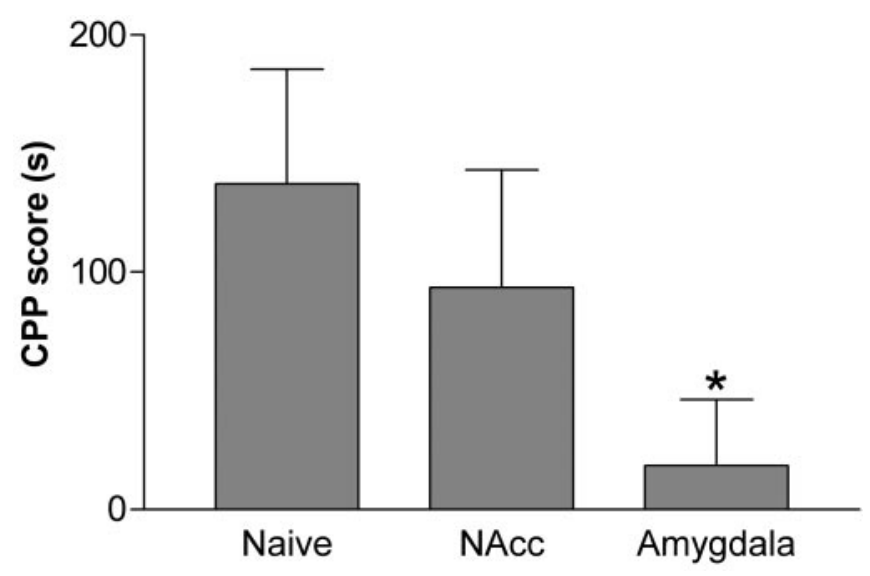

Figure 4. Preliminary findings: effects of $\mathrm{NK}_{1}$ receptor-expressing neuron ablation in the NAcc and dorsomedial CPu or amygdala on morphine reward behavior. Mean \pm SEM. CPP scores after conditioning with $3.0 \mathrm{mg} / \mathrm{kg}$ morphine in naive mice and those with ablation in the NAcc and dorsomedial CPu (NAcc) or in the amygdala. Mice with ablation of $\mathrm{NK}_{1}$ receptorexpressing neurons in the amygdala, but not the NAcc and dorsomedial $\mathrm{CPu}$, exhibited reductions in (PP scores. ${ }^{*} p<0.05$ versus naive (one-way ANOVA).

morphine $\left(10.0 \mathrm{mg} / \mathrm{kg} ; F_{(1,22)}=26.3 ; p<0.001\right.$; data not shown).

On the EPM, mice with ablation of $\mathrm{NK}_{1}$ receptor-expressing neurons in the amygdala spent less time in the open arms and made fewer entries into the open arms than naive mice. When compared with mice with control injections of SAP or SP into the
A
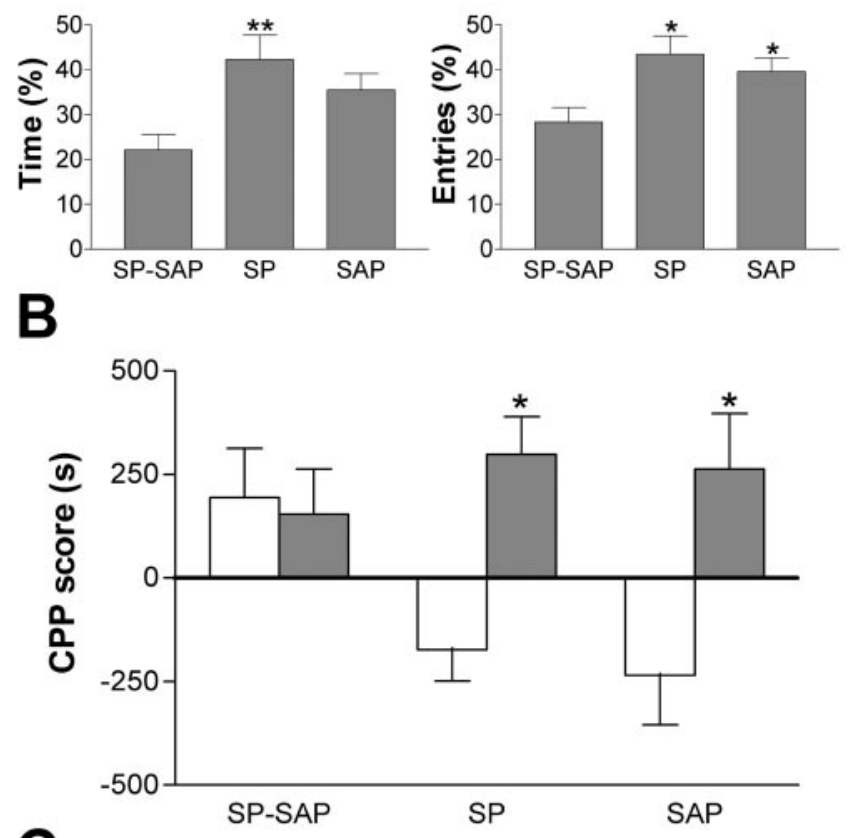

C

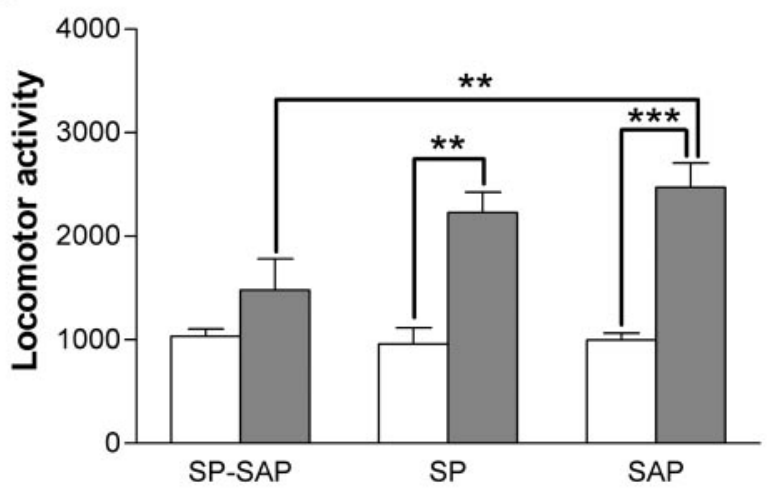

Figure 5. Effects of $\mathrm{NK}_{1}$ receptor-expressing neuron ablation in the amygdala on anxiety and morphine reward and stimulation. $A$, Mean \pm SEM time spent in the open arms of the EPM and mean \pm SEM number of entries into the open arms of the EPM in mice with ablation in the amygdala and mice receiving control injections of SP or SAP alone. Cell ablation caused decreases in the amount of time spent in the open arms of the maze and in the number of entries made into them relative to control groups. ${ }^{*} p<0.05 ;{ }^{* *} p<0.01$ versus SP-SAP ( post hoc Tukey comparisons). B, Mean \pm SEM. (PP scores in mice conditioned with saline or morphine $(3.0 \mathrm{mg} / \mathrm{kg})$. Mice injected with SP or SAP showed a significant CPP to morphine, whereas those with ablation of $\mathrm{NK}_{1}$ receptor-expressing neurons did not. ${ }^{*} p<0.05$ versus saline. C, Mean \pm SEM number of beam crosses in $10 \mathrm{~min}$, beginning $30 \mathrm{~min}$ after an injection of saline or morphine $(10.0 \mathrm{mg} / \mathrm{kg})$. Mice injected with SP or SAP into the amygdala showed a stimulant effect of morphine, but this was absent in mice with ablation of $\mathrm{NK}_{1}$ receptor-expressing neurons. ${ }^{* *} p<0.01 ;{ }^{* * *} p<0.001$.

amygdala, they tended to spend less time in the open arms and make fewer entries into them than both control groups (Fig. $5 A$ ). A one-way ANOVA of the time spent in the open arms by three groups of mice revealed a significant main effect of treatment $\left(F_{(2,88)}=5.32 ; p=0.007\right)$. Post hoc Tukey comparisons revealed a significant difference in the amount of time spent in the open arms between mice injected with SP-SAP and SP $(p=0.006)$, but the difference between SP-SAP- and SAP-injected mice narrowly missed statistical significance ( $p=0.058)$. There was no difference in the time spent in the open arms in SP- and SAP-injected mice $(p=0.476)$. A one-way ANOVA of the number of entries 
into the open arms also revealed a significant effect of treatment $\left(F_{(2,88)}=4.74 ; p=0.011\right)$. Post hoc Tukey comparisons revealed that the number of entries made by mice injected with SP-SAP was lower than that made by those injected with $\operatorname{SP}(p=0.013)$ and SAP ( $p=0.048)$, but there was no difference in the number of entries made by the latter two groups $(p=0.696)$. Together, ablation of $\mathrm{NK}_{1}$ receptor-expressing neurons in the amygdala caused an increase in anxiety as assessed on the EPM, which was manifest in both the time spent in the open arms of the maze and the number of entries made into them.

Mice with ablation of $\mathrm{NK}_{1}$ receptor-expressing neurons in the amygdala exhibited similar CPP scores after conditioning with morphine and saline. However, the CPP scores achieved by control mice injected with SP or SAP were higher after conditioning with morphine than with saline (Fig. 5B). A two-way ANOVA of CPP scores revealed a significant main effect of drug $\left(F_{(1,44)}=\right.$ $10.81 ; p=0.002)$ and a significant drug by treatment interaction $\left(F_{(2,44)}=3.96 ; p=0.026\right)$ but no significant main effect of treatment $\left(F_{(2,44)}=1.83 ; p=0.172\right)$. Post hoc Tukey comparisons revealed that CPP scores achieved by morphine- and salineconditioned mice injected with SP $(p=0.038)$ and SAP $(p=$ $0.046)$ differed significantly, but mice with ablation of $\mathrm{NK}_{1}$ receptor-expressing neurons did not display any such difference $(p=1.000)$. Mice with ablation of $\mathrm{NK}_{1}$ receptor-expressing neurons in the amygdala did not therefore exhibit a significant CPP to morphine at a dose of $3.0 \mathrm{mg} / \mathrm{kg}$. However, comparison across the three treatment groups failed to reveal significant differences in CPP scores after morphine conditioning $(p>0.9)$ or saline conditioning $(p>0.1)$. The observed effect therefore seems to be attributable to a decrease in morphine CPP scores coupled with an increase in the scores achieved by mice after saline conditioning. This increase in saline CPP scores brought about by ablation may be caused by the putatively aversive nature of the first injection being modulated by SP-SAP, possibly via its effect on anxiety levels.

Mice with ablation of $\mathrm{NK}_{1}$ receptor-expressing neurons in the amygdala exhibited similar levels of locomotor activity after an acute injection of saline to control mice injected with SP or SAP. After morphine administration $(10.0 \mathrm{mg} / \mathrm{kg})$, SP- and SAPinjected mice showed increases in locomotor activity, but this increase was reduced in SP-SAP-injected mice (Fig. 5C). A twoway ANOVA revealed significant main effects of drug $\left(F_{(1,32)}=\right.$ $61.5 ; p<0.001)$ and treatment $\left(F_{(2,32)}=6.39 ; p=0.005\right)$ and $\mathrm{a}$ significant drug by treatment interaction $\left(F_{(2,32)}=5.59 ; p=\right.$ 0.008). Post hoc Tukey comparisons revealed that morphine caused increases in ambulatory locomotor behavior relative to saline in mice injected with SP $(p=0.010)$ and SAP $(p<0.001)$, but this did not occur in SP-SAP-injected mice $(p=0.285)$. Furthermore, locomotor activity levels after morphine administration were lower in mice injected with SP-SAP than those injected with SAP $(p=0.007)$ but not those injected with SP ( $p=$ 0.257)

Ablation of $\mathrm{NK}_{1}$ receptor-expressing neurons in the amygdala therefore brought about increases in anxiety-related behavior on the EPM. Additionally, it caused a reduction in the rewarding and stimulant properties of morphine relative to vehicle controls and to mice undergoing control injections of SP or SAP alone.

Effects of cell ablation in the amygdala on cocaine reward Because $\mathrm{NK}_{1}{ }^{-/-}$mice do not show deficits in CPP to cocaine, the effects of $\mathrm{NK}_{1}$ receptor-expressing neuron ablation in the amygdala was assessed in an additional group of mice. After histological examination, seven mice were excluded from analysis be-

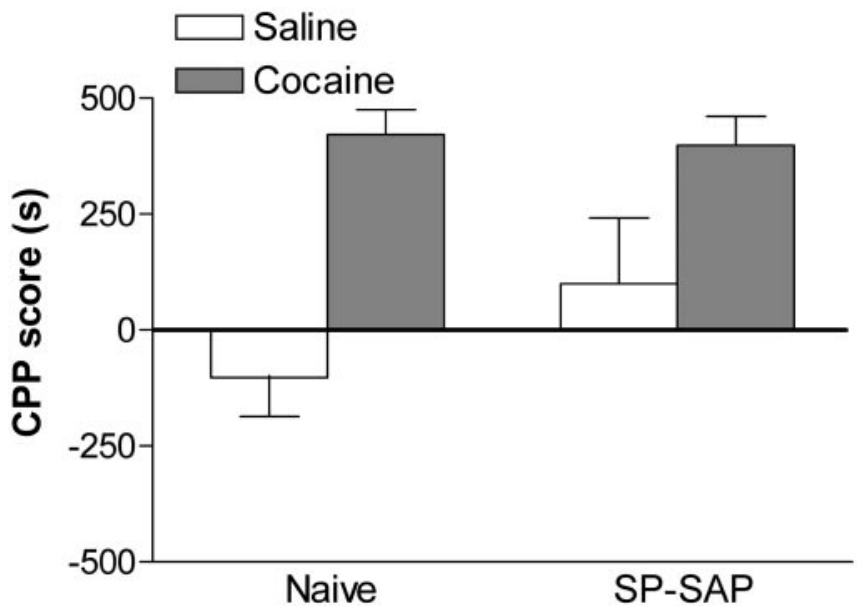

Figure 6. Effects of $\mathrm{NK}_{1}$ receptor-expressing neuron ablation in the amygdala on cocaine reward. Mean \pm SEM. CPP scores in naive mice and those with ablation of $\mathrm{NK}_{1}$ receptorexpressing neurons in the amygdala, after conditioning with saline or cocaine $(5.0 \mathrm{mg} / \mathrm{kg})$. Ablation did not affect cocaine reward.

cause of incomplete loss of $\mathrm{NK}_{1}$ receptor-expressing neurons. Naive mice and those with ablation of $\mathrm{NK}_{1}$ receptor-expressing neurons in the amygdala exhibited CPP to cocaine (Fig. 6). A two-way ANOVA revealed a significant main effect of drug $\left(F_{(1,46)}=28.3 ; p<0.001\right)$ but no significant main effect of treatment (naive vs SP-SAP; $F_{(1,46)}=1.10 ; p=0.300$ ) or drug by treatment interaction $\left(F_{(1,46)}=1.83 ; p=0.183\right)$. Reward to cocaine was therefore unaffected by the ablation of $\mathrm{NK}_{1}$ receptorexpressing neurons in the amygdala, with both naive and SPSAP-injected mice demonstrating CPP to cocaine at this dose.

\section{Discussion}

These data provide strong evidence for a role of $\mathrm{NK}_{1}$ receptorexpressing neurons within the amygdala in the mediation of morphine reward behaviors, as well as the modulation of anxiety. Ablation of $\mathrm{NK}_{1}$ receptor-expressing neurons in the amygdala brought about changes in EPM behavior characteristic of an increase in anxiety-related behaviors relative to SP- and SAPinjected controls. The amygdala is known to be involved in the mediation of behaviors related to anxiety, particularly in the association of environmental stimuli with fearful events (Phillips and LeDoux, 1992). Various studies have demonstrated the involvement of $\mathrm{NK}_{1}$ receptors in this role: maternal separation of guinea pig pups and immobilization stress in gerbils causes endocytosis of the receptor within the basolateral nucleus, which is blocked by the systemic administration of $\mathrm{NK}_{1}$ receptor antagonists (Kramer et al., 1998; Smith et al., 1999; Steinberg et al., 2002). However, systemic administration of a range of $\mathrm{NK}_{1}$ receptor antagonists produced anxiolytic-like effects in the gerbil EPM (Varty et al., 2002), and intra-amygdala injections of the $\mathrm{NK}_{1}$ receptor antagonist L 760735 reduce the amount of separation-induced vocalizations in the guinea pig (Boyce et al., 2001), observations that are consistent with those in $\mathrm{NK}_{1}{ }^{-1-}$ mice (Santarelli et al., 2001). These findings differ from the present observations, which suggest that loss of $\mathrm{NK}_{1}$ receptorexpressing neurons in the amygdala is anxiogenic. Although this discrepancy may be attributable to species differences, it is more likely to be attributable to the different nature of the two approaches: SP-SAP causes loss of $\mathrm{NK}_{1}$ receptor-mediated transmission as well as coexpressed receptors and neurotransmitters and interneuronal connections, as opposed to acute pharmaco- 
logical blockade (systemic or local) or lifelong loss of $\mathrm{NK}_{1}$ receptors throughout the body.

Ablation of $\mathrm{NK}_{1}$ receptor-expressing cells in the amygdala also abolished CPP to morphine, whereas it was maintained in both groups of control mice. Together with the observation that morphine hyperlocomotion was also reduced in these mice, this suggests that $\mathrm{NK}_{1}$ receptor-expressing neurons in the amygdala modulate behaviors related to morphine reward. This is specific to morphine because these mice displayed similar cocaine CPP scores to naive animals, thereby mirroring the observations in the $\mathrm{NK}_{1}{ }^{-/-}$mouse (Murtra et al., 2000).

The amygdala is known to be of importance in mediating the conditioned aspects of reward processes, particularly the connection between the basolateral nucleus and the NAcc, which is critical in mediating the control of behavior by discrete, rewardrelated stimuli (Cador et al., 1989; Everitt et al., 1989, 1991; Parkinson et al., 2001; Fuchs et al., 2002). A modulation of this output of the amygdala by neurons expressing the $\mathrm{NK}_{1}$ receptor could therefore be linked to the observed reductions in morphine reward. However, although the reinstatement of heroin-seeking behavior by drug-conditioned cues or drug priming can be abolished by inactivation of the basolateral nucleus (Fuchs and See, 2002), excitotoxic lesions of this nucleus do not impair the acquisition of intravenous heroin self-administration under continuous or second-order schedules of reinforcement (Alderson et al., 2000), suggesting that the basolateral amygdala may not be necessary for the acute rewarding effects of opiates or for cuemediated drug-seeking behavior. Although the loss of the few $\mathrm{NK}_{1}$ receptor-expressing cells from this region, as opposed to the cell bodies of the entire region, may explain the discrepancy between these present findings and those of Alderson et al. (2000), it is possible that such cells in other subnuclei of the amygdala may be more crucial. For example, the lateral nucleus of the amygdala is known to be of importance in CPP to amphetamine (Hiroi and White, 1991), as well as the conditioned cue preference task (McDonald and White, 1993). The central nucleus of the amygdala is also connected to the core of the NAcc and receives dense reciprocal dopaminergic afferents from the ventral tegmental area (Ungerstedt, 1971; Ben-Ari et al., 1975; Wallace et al., 1992): it is therefore well placed to control the dopaminergic input to the NAcc and possibly influence reward-related behaviors. Indeed, blockade of dopamine $\mathrm{D}_{2}$ receptors in this region reduces the acquisition and expression of CPP to morphine (Rezayof et al., 2002), whereas acute injection with morphine causes increases in the expression of SP here (Cantarella and Chahl, 1996). The mechanism by which loss of the $\mathrm{NK}_{1}$ receptor-expressing neurons in the amygdala brings about reductions in morphine reward-related behavior therefore remains a matter of speculation. Although there are few visible $\mathrm{NK}_{1}$ receptor-expressing neurons within the basolateral nucleus in the mouse, dendrites expressing the receptor are more prominent in the medial and central nuclei. Staining for $\beta \mathrm{Gal}$-positive nuclei within the brains of $\mathrm{NK}_{1}{ }^{-/-}$and heterozygous $\mathrm{NK}_{1}{ }^{+/-}$mice supports these findings: their somata are distributed throughout these subnuclei but are more numerous within the medial nucleus. Although the existence of only a few neurons does not preclude their importance in bringing about the observed behavioral changes, the more extensive cell loss from the medial nucleus of the amygdala suggests that this area may be of importance in our observations.

The neurochemical identity of the $\mathrm{NK}_{1}$ receptor-expressing neurons in the mouse amygdala remains unclear. In the basolateral nucleus of the guinea pig, the $\mathrm{NK}_{1}$ receptor is colocalized with glutamic acid decarboxylase, a marker for GABA, and local
SP microinjections increase the frequency of IPSPs (Maubach et al., 2001). Interestingly, the $\mathrm{CB}_{1}$ cannabinoid receptor is also expressed on the GABAergic interneurons of the basolateral nucleus, at least in the rat and the mouse (Katona et al., 2001; McDonald and Mascagni, 2001). $\mathrm{CB}_{1}^{-1-}$ mice display similar morphine-related behaviors to $\mathrm{NK}_{1}{ }^{-1-}$ mice (Ledent et al., 1999; Martin et al., 2000) and an anxiogenic-like profile in the lightdark box test (Martin et al., 2002), which is similar to that observed on the EPM here. It is possible that the $\mathrm{CB}_{1}$ and $\mathrm{NK}_{1}$ receptors are localized on the same neurons within this nucleus of the amygdala; these neurons may therefore be central to the similar effects of deletion of the $\mathrm{NK}_{1}$ and the $\mathrm{CB}_{1}$ receptors.

An additional area of uncertainty is the origin of the ligand for the $\mathrm{NK}_{1}$ receptor in the amygdala. Retrograde tracing studies have demonstrated that the ventrolateral hypothalamus sends a modest SP projection to the medial nucleus in the guinea pig (Ricciardi and Blaustein, 1994) and that the rat central nucleus receives SP projections from the parabrachial and caudal laterodorsal tegmental nuclei (Yamano et al., 1988; Block et al., 1989; Petrov et al., 1994). SP is also expressed in cell bodies and fibers within the medial and central nuclei (Roberts et al., 1982; Cassell et al., 1986; Cassell and Gray, 1989; Malsbury and McKay, 1989): these neurons may make SP synapses onto $\mathrm{NK}_{1}$ receptorexpressing cells within the same or other subnuclei in the amygdala. Indeed, the presence of a short SP projection from the medial to the central nucleus of the amygdala has been suggested (Emson et al., 1978).

The behavioral effects of lesions of the tegmental pendunculopontine nucleus in drug-naive rats are similar to those of $\mathrm{NK}_{1}{ }^{-1-}$ mice: they prevent the acquisition of CPP to morphine, but not cocaine, without affecting the analgesic properties of morphine (Bechara and van der Kooy, 1989, 1992; Olmstead and Franklin, 1993; Parker and van der Kooy, 1995). Although the direct anatomical connection from this nucleus to the central and medial nuclei of the amygdala is minor (Hallanger and Wainer, 1988), an intriguing possibility is that these connections contain $\mathrm{SP}$, either in direct connections or via a polysynaptic pathway, thus providing a link between the effects of these lesions and the results presented here. This hypothesis is supported by the observation that a few of the connections from the tegmental pendunculopontine nucleus to the amygdala are cholinergic in the rat (Hallanger and Wainer, 1988), and, in man, SP is coexpressed with acetylcholine in this nucleus (Halliday et al., 1990; Gai et al., 1993).

$\mathrm{NK}_{1}$ receptor-expressing neurons in other areas of the brain may also be of importance in morphine reward. For example, the locus ceruleus, which has been implicated in opiate dependence (Nestler et al., 1994, 1999) and expresses $\mathrm{NK}_{1}$ receptors on its noradrenergic projection neurons (Moyse et al., 1997; Chen et al., 2000; Santarelli et al., 2001), may be involved in the effects of the $\mathrm{NK}_{1}$ receptor. Alternatively, the nucleus basalis magnocellularis may be of importance, because microinjections of SP here support place preference and increase dopamine release within the NAcc (Holzhäuer-Oitzl et al., 1988; Boix et al., 1995; Hasenöhrl et al., 1998). Additional work is required to assess the role of $\mathrm{NK}_{1}$ receptors in these brain regions, which may act along with those in the amygdala to modulate the motivational responses to opiate administration.

\section{References}

Alderson HL, Robbins TW, Everitt BJ (2000) The effects of excitotoxic lesions of the basolateral amygdala on the acquisition of heroin-seeking behaviour in rats. Psychopharmacology 153:111-119. 
Bardo MT, Bevins RA (2000) Conditioned place preference: what does it add to our preclinical understanding of drug reward? Psychopharmacology 153:31-43.

Bechara A, van der Kooy D (1989) The tegmental pedunculopontine nucleus: a brainstem output of the limbic system critical for the conditioned place preferences produced by morphine and amphetamine. J Neurosci 9:3400-3409.

Bechara A, van der Kooy D (1992) A single brain stem substrate mediates the motivational effects of both opiates and food in nondeprived rats but not in deprived rats. Behav Neurosci 106:351-363.

Ben-Ari Y, Zigmond RE, Moore KE (1975) Regional distribution of tyrosine hydroxylase, norepinephrine and dopamine within the amygdaloid complex of the rat. Brain Res 87:96-101.

Block CH, Hoffman G, Kapp BS (1989) Peptide-containing pathways from the parabrachial complex to the central nucleus of the amygdala. Peptides 10:465-471.

Boix F, Sandor P, Nogueira PJ, Huston JP, Schwarting RK (1995) Relationship between dopamine release in nucleus accumbens and place preference induced by substance $\mathrm{P}$ injected into the nucleus basalis magnocellularis region. Neuroscience 64:1045-1055.

Boyce S, Smith D, Carlson E, Hewson L, Rigby M, O’Donnell R, Harrison T, Rupniak NM (2001) Intra-amygdala injection of the substance P $\left(\mathrm{NK}_{1}\right.$ receptor) antagonist L-760735 inhibits neonatal vocalisations in guineapigs. Neuropharmacology 41:130-137.

Cador M, Robbins TW, Everitt BJ (1989) Involvement of the amygdala in stimulus-reward associations: interaction with the ventral striatum. Neuroscience 30:77-86

Cantarella PA, Chahl LA (1996) Acute effects of morphine on Substance P concentrations in microdissected regions of guinea-pig brain. Behav Pharmacol 7:470-476.

Cassell MD, Gray TS (1989) Morphology of peptide-immunoreactive neurons in the rat central nucleus of the amygdala. J Comp Neurol 281:320-333.

Cassell MD, Gray TS, Kiss JZ (1986) Neuronal architecture in the rat central nucleus of the amygdala: a cytological, hodological, and immunocytochemical study. J Comp Neurol 246:478-499.

Chen LW, Wei LC, Liu HL, Rao ZR (2000) Noradrenergic neurons expressing substance $\mathrm{P}$ receptor (NK1) in the locus coeruleus complex: a double immunofluorescence study in the rat. Brain Res 873:155-159.

De Felipe C, Herrero JF, O’Brien JA, Palmer JA, Doyle CA, Smith AJ, Laird JM, Belmonte C, Cervero F, Hunt SP (1998) Altered nociception, analgesia and aggression in mice lacking the receptor for substance P. Nature 392:394-397.

Di Chiara G, Tanda G, Bassareo V, Pontieri F, Acquas E, Fenu S, Cadoni C, Carboni E (1999) Drug addiction as a disorder of associative learning. Role of nucleus accumbens shell/extended amygdala dopamine. Ann NY Acad Sci 877:461-485.

Emson PC, Jessell T, Paxinos G, Cuello AC (1978) Substance P in the amygdaloid complex, bed nucleus and stria terminalis of the rat brain. Brain Res 149:97-105.

Everitt BJ, Cador M, Robbins TW (1989) Interactions between the amygdala and ventral striatum in stimulus-reward associations: studies using a second-order schedule of sexual reinforcement. Neuroscience 30:63-75.

Everitt BJ, Morris KA, O’Brien A, Robbins TW (1991) The basolateral amygdala-ventral striatal system and conditioned place preference: further evidence of limbic-striatal interactions underlying reward-related processes. Neuroscience 42:1-18.

Franklin KBJ, Paxinos G (1997) The mouse brain in stereotaxic coordinates. San Diego: Academic.

Fuchs RA, See RE (2002) Basolateral amygdala inactivation abolishes conditioned stimulus- and heroin-induced reinstatement of extinguished heroin-seeking behavior in rats. Psychopharmacology 160:425-433.

Fuchs RA, Weber SM, Rice HJ, Neisewander JL (2002) Effects of excitotoxic lesions of the basolateral amygdala on cocaine-seeking behavior and cocaine conditioned place preference in rats. Brain Res 929:15-25.

Gai WP, Blumbergs PC, Geffen LB, Blessing WW (1993) Galanincontaining fibers innervate substance P-containing neurons in the pedunculopontine tegmental nucleus in humans. Brain Res 618:135-141.

Gerfen CR (1991) Substance P (neurokinin-1) receptor mRNA is selectively expressed in cholinergic neurons in the striatum and basal forebrain. Brain Res 556:165-170.

Hallanger AE, Wainer BH (1988) Ascending projections from the peduncu- lopontine tegmental nucleus and the adjacent mesopontine tegmentum in the rat. J Comp Neurol 274:483-515.

Halliday GM, Gai WP, Blessing WW, Geffen LB (1990) Substance $\mathrm{P}$-containing neurons in the pontomesencephalic tegmentum of the human brain. Neuroscience 39:81-96.

Handley SL, Mithani S (1984) Effects of alpha-adrenoceptor agonists and antagonists in a maze-exploration model of "fear"-motivated behaviour. Naunyn Schmiedebergs Arch Pharmacol 327:1-5.

Hasenöhrl RU, Frisch C, Huston JP (1998) Evidence for anatomical specificity for the reinforcing effects of SP in the nucleus basalis magnocellularis. NeuroReport 9:7-10.

Hiroi N, White NM (1991) The lateral nucleus of the amygdala mediates expression of the amphetamine-produced conditioned place preference. J Neurosci 11:2107-2116.

Holzhäuer-Oitzl MS, Hasenöhrl R, Huston JP (1988) Reinforcing properties of substance $\mathrm{P}$ in the region of the nucleus basalis magnocellularis in rats. Neuropharmacology 27:749-756.

Kaneko T, Shigemoto R, Nakanishi S, Mizuno N (1993) Substance P receptor-immunoreactive neurons in the rat neostriatum are segregated into somatostatinergic and cholinergic aspiny neurons. Brain Res 631:297-303.

Katona I, Rancz EA, Acsády L, Ledent C, Mackie K, Hájos N, Freund TF (2001) Distribution of CB1 cannabinoid receptors in the amygdala and their role in the control of GABAergic transmission. J Neurosci 21:9506-9518.

Kramer MS, Cutler N, Feighner J, Shrivastava R, Carman J, Sramek JJ, Reines SA, Liu G, Snavely D, Wyatt-Knowles E, Hale JJ, Mills SG, MacCoss M, Swain CJ, Harrison T, Hill RG, Hefti F, Scolnick EM, Cascieri MA, Chicchi GG, Sadowski S, Williams AR, Hewson L, Smith D, Rupniak NM (1998) Distinct mechanism for antidepressant activity by blockade of central substance $P$ receptors. Science 281:1640-1645.

Ledent C, Valverde O, Cossu G, Petitet F, Aubert JF, Beslot F, Bohme GA, Imperato A, Pedrazzini T, Roques BP, Vassart G, Fratta W, Parmentier M (1999) Unresponsiveness to cannabinoids and reduced addictive effects of opiates in CB1 receptor knockout mice. Science 283:401-404.

Malsbury CW, McKay K (1989) Sex difference in the substance P-immunoreactive innervation of the medial nucleus of the amygdala. Brain Res Bull 23:561-567.

Mantyh PW, Rogers SD, Honore P, Allen BJ, Ghilardi JR, Li J, Daughters RS, Lappi DA, Wiley RG, Simone DA (1997) Inhibition of hyperalgesia by ablation of lamina I spinal neurons expressing the substance P receptor. Science 278:275-279.

Martin M, Ledent C, Parmentier M, Maldonado R, Valverde O (2000) Cocaine, but not morphine, induces conditioned place preference and sensitization to locomotor responses in CB1 knockout mice. Eur J Neurosci 12:4038-4046.

Martin M, Ledent C, Parmentier M, Maldonado R, Valverde O (2002) Involvement of CB1 cannabinoid receptors in emotional behaviour. Psychopharmacology 159:379-387.

Maubach KA, Martin K, Smith DW, Hewson L, Frankshun RA, Harrison T, Seabrook GR (2001) Substance P stimulates inhibitory synaptic transmission in the guinea pig basolateral amygdala in vitro. Neuropharmacology 40:806-817.

McDonald AJ, Mascagni F (2001) Localization of the CB1 type cannabinoid receptor in the rat basolateral amygdala: high concentrations in a subpopulation of cholecystokinin-containing interneurons. Neuroscience 107:641-652.

McDonald RJ, White NM (1993) A triple dissociation of memory systems: hippocampus, amygdala, and dorsal striatum. Behav Neurosci 107:3-22.

Montgomery KC (1955) The relation between fear induced by novel stimulation and exploratory drive. J Comp Physiol Psychol 48:254-260.

Moyse E, Marcel D, Leonard K, Beaudet A (1997) Electron microscopic distribution of $\mathrm{mu}$ opioid receptors on noradrenergic neurons of the locus coeruleus. Eur J Neurosci 9:128-139.

Murtra P, Sheasby AM, Hunt SP, De Felipe C (2000) Rewarding effects of opiates are absent in mice lacking the receptor for substance P. Nature 405:180-183.

Nakaya Y, Kaneko T, Shigemoto R, Nakanishi S, Mizuno N (1994) Immunohistochemical localization of substance $P$ receptor in the central nervous system of the adult rat. J Comp Neurol 347:249-274.

Nestler EJ, Alreja M, Aghajanian GK (1994) Molecular and cellular mecha- 
nisms of opiate action: studies in the rat locus coeruleus. Brain Res Bull 35:521-528.

Nestler EJ, Alreja M, Aghajanian GK (1999) Molecular control of locus coeruleus neurotransmission. Biol Psychiatry 46:1131-1139.

Nichols ML, Allen BJ, Rogers SD, Ghilardi JR, Honore P, Luger NM, Finke MP, Li J, Lappi DA, Simone DA, Mantyh PW (1999) Transmission of chronic nociception by spinal neurons expressing the substance $P$ receptor. Science 286:1558-1561.

Olmstead MC, Franklin KB (1993) Effects of pedunculopontine tegmental nucleus lesions on morphine-induced conditioned place preference and analgesia in the formalin test. Neuroscience 57:411-418.

Parker JL, van der Kooy D (1995) Tegmental pedunculopontine nucleus lesions do not block cocaine reward. Pharmacol Biochem Behav 52:77-83.

Parkinson JA, Crofts HS, McGuigan M, Tomic DL, Everitt BJ, Roberts AC (2001) The role of the primate amygdala in conditioned reinforcement. J Neurosci 21:7770-7780.

Petrov T, Krukoff TL, Jhamandas JH (1994) Chemically defined collateral projections from the pons to the central nucleus of the amygdala and hypothalamic paraventricular nucleus in the rat. Cell Tissue Res 277:289-295.

Phillips RG, LeDoux JE (1992) Differential contribution of amygdala and hippocampus to cued and contextual fear conditioning. Behav Neurosci 106:274-285.

Rezayof A, Zarrindast MR, Sahraei H, Haeri-Rohani AH (2002) Involvement of dopamine D2 receptors of the central amygdala on the acquisition and expression of morphine-induced place preference in rat. Pharmacol Biochem Behav 74:187-197.

Ricciardi KH, Blaustein JD (1994) Projections from ventrolateral hypothalamic neurons containing progestin receptor- and substance $\mathrm{P}$-immunoreactivity to specific forebrain and midbrain areas in female guinea pigs. J Neuroendocrinol 6:135-144.

Ripley TL, Gadd CA, De Felipe C, Hunt SP, Stephens DN (2002) Lack of self-administration and behavioural sensitisation to morphine, but not cocaine, in mice lacking NK1 receptors. Neuropharmacology 43:1258-1268.

Robbins TW, Everitt BJ (1996) Neurobehavioural mechanisms of reward and motivation. Curr Opin Neurobiol 6:228-236.

Roberts GW, Woodhams PL, Polak JM, Crow TJ (1982) Distribution of neuropeptides in the limbic system of the rat: the amygdaloid complex. Neuroscience 7:99-131.

Rupniak NM, Carlson EC, Harrison T, Oates B, Seward E, Owen S, De Felipe
C, Hunt S, Wheeldon A (2000) Pharmacological blockade or genetic deletion of substance $\mathrm{P}\left(\mathrm{NK}_{1}\right)$ receptors attenuates neonatal vocalisation in guinea-pigs and mice. Neuropharmacology 39:1413-1421.

Santarelli L, Gobbi G, Debs PC, Sibille EL, Blier P, Hen R, Heath MJ (2001) Genetic and pharmacological disruption of neurokinin 1 receptor function decreases anxiety-related behaviors and increases serotonergic function. Proc Natl Acad Sci USA 98:1912-1917.

Smith DW, Hewson L, Fuller P, Williams AR, Wheeldon A, Rupniak NM) (1999) The substance P antagonist L-760, 735 inhibits stress-induced $\mathrm{NK}_{1}$ receptor internalisation in the basolateral amygdala. Brain Res 848:90-95.

Steinberg R, Alonso R, Rouquier L, Desvignes C, Michaud JC, Cudennec A, Jung M, Simiand J, Griebel G, Emonds-Alt X, Le Fur G, Soubrié P (2002) SSR240600 [(R)-2-(1-\{2-[4-\{2-[3, 5-bis(trifluoromethyl)phenyl]acetyl $\}$ 2-(3, 4-dichloro phenyl)-2-morpholinyl]ethyl\}-4-piperidinyl)-2-methylpropanamide], a centrally active nonpeptide antagonist of the tachykinin neurokinin 1 receptor. II. Neurochemical and behavioral characterization. J Pharmacol Exp Ther 303:1180-1188.

Truitt WA, Coolen LM (2002) Identification of a potential ejaculation generator in the spinal cord. Science 297:1566-1569.

Ungerstedt U (1971) Stereotaxic mapping of the monoamine pathways in the rat brain. Acta Physiol Scand Suppl 367:1-48.

Varty GB, Cohen-Williams ME, Morgan CA, Pylak U, Duffy RA, Lachowicz JE, Carey GJ, Coffin VL (2002) The gerbil elevated plus-maze II: anxiolytic-like effects of selective neurokinin NK1 receptor antagonists. Neuropsychopharmacology 27:371-379.

Wallace DM, Magnuson DJ, Gray TS (1992) Organization of amygdaloid projections to brainstem dopaminergic, noradrenergic, and adrenergic cell groups in the rat. Brain Res Bull 28:447-454.

Wang H, Germanson TP, Guyenet PG (2002) Depressor and tachypneic responses to chemical stimulation of the ventral respiratory group are reduced by ablation of neurokinin-1 receptor-expressing neurons. J Neurosci 22:3755-3764.

Wiley RG, Lappi DA (1997) Destruction of neurokinin-1 receptor expressing cells in vitro and in vivo using substance P-saporin in rats. Neurosci Lett 230:97-100.

Yamano M, Hillyard CJ, Girgis S, MacIntyre I, Emson PC, Tohyama M (1988) Presence of a substance P-like immunoreactive neurone system from the parabrachial area to the central amygdaloid nucleus of the rat with reference to coexistence with calcitonin gene-related peptide. Brain Res 451:179-188. 